\title{
Pathology of Social Violence Phenomenon in Ardabil Province: A Qualitative Study
}

\author{
Shahram Habibzadeh ${ }^{1}$, Farhad Poufarzi ${ }^{2}$, Mohammad Mehrtak ${ }^{3}$, Saied Sadeghiyeh-Ahari ${ }^{2}$, Mehdi Jafari-Oori ${ }^{4}$, \\ Karim Hajizadeh-Bastani ${ }^{5} \&$ Arezoo Azari $^{6}$ \\ ${ }^{1}$ Department of Infectious Diseases, Ardabil University of Medical Sciences, Ardabil, Iran \\ ${ }^{2}$ Department of Social Medicine, Ardabil University of Medical Sciences, Ardabil, Iran \\ ${ }^{3}$ Faculty of Medical and Paramedical, Ardabil University of Medical Sciences, Ardabil, Iran \\ ${ }^{4}$ Meshkin-Shahr Health Institute, Ardabil University of Medical Sciences, Ardabil, Iran \\ ${ }^{5}$ Department of Archaeology, University of Mohaghegh Ardabili, Ardabil, Iran \\ ${ }^{6}$ Molecular Cell Biology, Ardabil, Iran \\ Correspondence: Farhad Poufarzi, Department of Community Medicine, Ardabil University of Medical Sciences, \\ Ardabil, Iran. Tel: 98-914-151-1861. E-mail: f.pourfarzi@arums.ac.ir
}

Received: November 29, 2015 Accepted: January 1, 2016 Online Published: February 24, 2016

doi:10.5539/gjhs.v8n10p15 URL: http://dx.doi.org/10.5539/gjhs.v8n10p15

\begin{abstract}
Introduction: In all human societies, domestic violence is known as a threat. Violence is imposing one's will on others through mental pressure and physical damage then can cause a feeling of anxiety and insecurity in them, especially for the weaker and more vulnerable groups such as women, children, elderly and minority groups who are the victims of oppression and socioeconomic inequalities. According to statistics, Ardabil, in comparison with other Iran's provinces, has the most number of violent crimes. This qualitative research was conducted with the aim of exploring pathological phenomena of social violence in Ardabil province.
\end{abstract}

Methods: this qualitative study was conducted with expert panel. Eighteen participants were selected with targeted sampling method from professors and the heads of the administrative offices who were linked to the phenomenon of social violence and have rich experiences with the social violence issues. After obtaining an informed consent from the participants, expert panel were conducted in two sessions of 150 minutes. At each session all discourse was recorded and after that, immediately transcribed verbatim. Then, the codes, sub-themes and the themes were obtained.

Results: The five main extracted themes included: social, historical and anthropological, cultural, economic and regional factors and 13 sub-themes were classified.

Conclusion: Social, economic, cultural and regional structure, which have been formed and institutionalized in the society over the years, can be influenced and changed by government policies and a variety of programs.

Keywords: pathology, social violence, aggressiveness, Ardabil province

\section{Introduction}

Social violence is known as a major threat to public health (Hedin, 2000). According to the World Health Organization's definition, abuse or violence is defined as a using of intentional physical force or power that causes apparent or hidden injuries, psychological damage, growth disorder, various deprivation and even death (Talas, Kocaöz, \& Akgüç, 2011; Unicef, 1999). Violence is a behavior with the aim of harming oneself or others by someone and its scope is from insults, humiliation, exceed and beatings up to crimes such as destruction of property and extensive murder. In the most general meaning, violence can be considered as an imposing one's will to others through pressure and physical or mental harms. Therefore the Violence can cause a feeling of anxiety and insecurity among those that are poor and vulnerable groups such as women, children, elderly and other minority groups. The extensive and increasing occurrence of the social violence in addition to the direct victims, can affect friends or relatives of them and disrupt the security and social mental health too (Cantera, Cervantes, \& Blanch, 2008; Savenstani, 2007). 
In explaining of original and nature of violence and crime, different theorists pointed out the set of biological, psychological, social and cultural agents (Khanzadeh \& Taher, 2014). Neurological research revealed some structural and functional defects in the frontal, temporal and cortical of antisocial individuals and their deficiencies in verbal, spatial and executive abilities (Schug, Gao, Glenn, Yang, \& Raine, 2010).

Always social control and monitor has been recognized as a barrier to social violence occurrence. A safe and steady society should be described by the rules and regulations, or by a set of actions against threats that could endanger the health of persons or the society (Cozens, 2002). The economic effects of the social violence and its relationship with poverty, inequality and injustice recognized as a big concern in the international community (Moser \& Mcllwaine, 2006). And it was known that there is a significant negative relationship between social violence and economic growth (Collier, 2003).

The experience of violence in the childhood period increases likelihood of violence incidence in the adulthood (Burazeri, Qirjako, Roshi, \& Brand, 2011). So it can be said that violent behaviors may transfer from one generation to the next. There is strong evidence that many children who were witnesses of violence in their families, subsequently, would have behavioral and psychological problems in the adulthood (McCloskey, 2011; Topham, Larson, \& Holman, 2005). And at all, these problems can cause negative consequences in interpersonal relationships in the adulthood. Because the abused children may imagine that using of quarrelsome behaviors and aggression can be as a main means of solving social conflicts (Huth-Bocks \& Hughes, 2008). The results of researches indicated that the incidence of violence in unhealthy families is much more than healthy families. One of the important psychological factor that associated with violence and mentioned in many internal and external research, is the personality characteristics of individuals (Le Corff \& Toupin, 2009).

Some studies showed that there is a direct relationship between the numbers of social factors such as education, occupation and level of individual income with an incidence of violence (Saberian, Atash, \& Behnam, 2005). And other studies emphasized that identifying of violence roots and its causes and also individuals at risk in the childhood, who may be potentially at risk of committing of violent behavior, are very effective in designing of programs and preventive interventions (Fritz, Wiklund, Koposov, af Klinteberg, \& Ruchkin, 2008).

Adaptive behaviors in dealing with violence, may lead to increasing or decreasing of violence or stresses related to it (Kaye, Ekström, Johansson, Bantebya, \& Mirembe, 2007) and on the other hand can affect individual mental health (Meyer, Wagner, \& Dutton, 2010). Many poor adaptive behaviors and emotional states such as drug abuse, excessive alcohol use, acts of violence to others, panic or depression occurs in trying to comply with violence (Carlson, 1997; Taherkhani et al., 2015). Although the Social and cultural atmosphere in Iran is usually friendship, kindness and mutual respect, But surprisingly and unfortunately social violence has much prevalence and incidence in Ardabil in comparing with the other Iran's provinces. Due to the importance of the social violence and it, s prevalence in the Ardabil and in order to explore its involved factors, this qualitative study designed to explain the different aspects of this phenomenon and its management.

\section{Methods}

The study was performed in 2015 with an expert panel based qualitative study using content analysis. We used content analysis as a research method for the subjective interpretation of the content of interview data through a systematic classification process of coding and identifying concepts or patterns. The participants were Ardabil province office managers who linked to the control of social violence and Professors in the field of sociology and psychology with rich experiences. The participant selection criteria were rich experience and having a history of addressing to the social violence issues. In consequence of using purposive sampling, 18 participants based on data saturation and replication of data, were obtained. Each session lasted about 90-150 minutes. All expert panel sessions were conducted in the conference Hall of Ardabil University. All discourses recorded with the informed consent of the participants and then transcribed verbatim immediately by the researcher. Thematic content analysis was used for data analysis with the extraction of codes, categories and themes. The MAXqda10 software was used.

The validity and reliability of this study rooted in four axes which including credibility, dependability, confirmability and transferability. Credibility means that the translation of the interviews was been acceptable by participants, in this study member check was performed with carefully and there was continuously communication with participants and corrective opinions of professors and their comments were applied to analysis and data extraction. In addition the discourse transcripts, the extracted themes and sub-themes were provided for professors and finally theme comments were applied again.

For dependability, data collection whit triangulation methods (Boswell \& Cannon, 2012) for example Field notes and memos were used. Also in data gathering, the variety of participants, who were with key positions in the 
general offices of Ardabil province, used (Boswell \& Cannon, 2012; Mehrtak, Vatankhah, \& delgoshaei, 2014). In relation to confirmability of result, extracted Codes were confirmed by the participants (Speziale et al., 2011). Finally, for transferability, the results of the study reviewed and were approved by six scientific boards that were out of the study and were familiar with qualitative study (Speziale et al., 2011).

Ethical clearance of the study was obtained from the ethics committee of the university of Ardabil medical science and informed consent was also obtained and all participants were informed that they could refuse to participate or withdraw from the study at any time.

\section{Results}

The participants included 14 males and 4 females. According to Table 1, the result of study classified in 5 main themes and 13 sub-themes.

Table 1. Major and minor themes extracted from the interviews and group discussions

\begin{tabular}{|c|c|c|}
\hline Theme & Sub-theme & Sample of quote \\
\hline \multirow{4}{*}{ Social Factors } & Social Capital & $\begin{array}{l}\text { "Our social capital has decreased. Social capital means that How much we } \\
\text { trust to each other? How much do we trust to managers? How much we } \\
\text { ready to do nonprofit work together? See why violence in } \\
\text { Sistan-Baluchistan is too little? Because their social capital is high." }\end{array}$ \\
\hline & Social skills & $\begin{array}{l}\text { The ability control of nervousness and resentment and maintaining } \\
\text { composure in dealing with violent events can influence on its incident" }\end{array}$ \\
\hline & $\begin{array}{l}\text { Legal and rule } \\
\text { vacuums }\end{array}$ & $\begin{array}{l}\text { "We must see that what is our legal vacuum that the violence hasn't been } \\
\text { stopped yet. Is the lack of timely implementation of verdict could be } \\
\text { effective? }\end{array}$ \\
\hline & Rights of citizenship & $\begin{array}{l}\text { "One of the violence reasons in society, is insufficient awareness of } \\
\text { population with citizenship rights. The first thing that should happen in } \\
\text { this society is the definition of a citizen's rights and respect for it... }\end{array}$ \\
\hline \multirow{2}{*}{$\begin{array}{l}\text { Anthropological } \\
\text { Historical factors }\end{array}$} & $\begin{array}{l}\text { Historical } \\
\text { Background }\end{array}$ & $\begin{array}{l}\text { "These thousands of years in their historical memory, in themselves } \\
\text { biological gene carries out personal encounter with the issue of violence } \\
\text { and Invasion" }\end{array}$ \\
\hline & Anthropological & $\begin{array}{l}\text { The society of animal husbandry, because of the incompetence and lack of } \\
\text { income immigrate to the city. Now } 85 \% \text { of Ardabil's people are rural and } \\
\text { tribal population }\end{array}$ \\
\hline \multirow{3}{*}{ Cultural factors } & $\begin{array}{l}\text { The quality of family } \\
\text { relationships }\end{array}$ & $\begin{array}{l}\text { "One of the important components of the prevalence of violence in the } \\
\text { society is the quality of family relationships. This means that how much is } \\
\text { the amount of intimacy and understanding of family members among } \\
\text { themselves, how much is the insult and humiliation among each other " }\end{array}$ \\
\hline & $\begin{array}{l}\text { Attention to the next } \\
\text { generation }\end{array}$ & $\begin{array}{l}\text { "The coming generation, should were given more attention. The children } \\
\text { who were trained, should were given more attention. Those who are over } \\
18 \text { years, I don't say that their changes is not possible, but is too difficult } \\
\text { The kindergartens and primary schools are infrastructure which usually } \\
\text { more influence to growth and training of children. }\end{array}$ \\
\hline & $\begin{array}{l}\text { Education and } \\
\text { empowerment of } \\
\text { women }\end{array}$ & $\begin{array}{l}\text { "Empowering of women, finally reduce violence. Namely, one of the } \\
\text { causes of violence against women is that she isn't powerful and aware of } \\
\text { her rights and had to accede the domestic violence. If women become } \\
\text { literate, finally violence can reduce" }\end{array}$ \\
\hline \multirow[b]{2}{*}{ Economic factors } & Poverty & $\begin{array}{l}\text { "If you want to removed violence from the community, you should do } \\
\text { something that people could feel honorable life with eight-hour working". }\end{array}$ \\
\hline & $\begin{array}{l}\text { Categories and } \\
\text { economic gap }\end{array}$ & $\begin{array}{l}\text { "There is a terrible social gap in Ardabil province. The authorities should } \\
\text { do something that these gaps come down. And we are able to get closer to } \\
\text { social justice." }\end{array}$ \\
\hline \multirow[t]{2}{*}{ Regional factors } & $\begin{array}{l}\text { Space and } \\
\text { Somatology }\end{array}$ & $\begin{array}{l}\text { "We gave to intrinsically residential homes, health care services that it } \\
\text { causes heavy traffic congestion and someone acts violence and aggression } \\
\text { to theirs, in fact we have imposed him this violence and aggression". }\end{array}$ \\
\hline & Bio ecology & $\begin{array}{l}\text { "You will find that anywhere which there be agriculture and animal } \\
\text { husbandry, there will be too much violence" }\end{array}$ \\
\hline
\end{tabular}




\subsection{Social Factors}

\subsubsection{Social Capital}

The social capital is something more than the physical, financial and human capital. The Social capital is a competency or informal norm that improves empathy and cooperation between people and the institutions of a society. Every community requires in addition to knowledgeable and experienced persons, facilities and material tool, also some factors such as trust, commitment, responsibility and ... which are the social capital. Whatever the social capital is in higher level, the trust of people to each other can become more in doing of social affairs. The participants have known that drop in social capital is one of the reasons of incidence and prevalence of violence in the Ardabil. One participant said that:

"Our social capital has decreased. Social capital means that how much we trust to each other? How much do we trust to managers? How much do we ready to do nonprofit work to each other? See why violence is too low in Sistan-Baluchistan province? Because their social capital is at high level. "In this regard another participant explained that:

"The reduction of violence incidence can be done by the hands of senior policy-makers. They should do a one thing that able us in moving in the direction of social capital promotion. For example, the government could lead to the formation and strengthening of the social capital by implementation targeted legislation. How we can alert our government departments in doing of their essential duties? How we can inform and aware them? ... We must use our executive and training facilities to institutionalize social capital, so subsequently people can find their status and dignity. A one, who doesn't have human and social dignity, he/she feels worthlessness. In this situation, what we can expect him? If we don't have the social capital, what takes its place? Injury and damage take its place. Social capital gives us confidence, a sense of participation, compassion and empathy. Well, if these are not be, what takes their place? Lack of commitment, lack of standards and norms."

\subsubsection{Social Skills}

Atmosphere of violence can be created because the lack of or impossibility of dialogue, tolerance and compromise habits of people to each other. Many of these events happened because the absence of any dialogue between two sides of the argument and in fact the past dialogue cultural communication of the Iranian people does not exist today. Principally, from a healthy person, it can't be expected violence or aggression behaviors. Some apparently healthy individuals suffering from personality disorders and has aggressive verbal or behaviors. Suspicion, pessimism and furiously behaviors often can isolate the aggressive individual and remain him deprived of other support. There is no doubt that the aggressive individuals in comparing with quiet and ordinary people are less successful in their social interactions.

A participant in this regard said:

"Anger what in its low or in the madness level can be as a tragic. We suppose that we can show ourselves only whit anger, but this belief is clearly wrong and in fact we can use numerous other positive ways for expressing ourselves. The ability control of nervousness and resentment and maintaining composure in dealing with violent events can influence its incident"

And other participating stated:

"The reservation and principle of dialogue is to respect to other opinions or ideas and really we must trace it. Do you know that when I can talk you without any arguments? When we value these rules that a human as a thinking existing should be respected his votes and opinions. If we reach to it, we can say, Mr. Lani with all respect to your opinion, but I totally disagree with you, and then it can't be occurred any problem"

\subsubsection{Legal and Rule Vacuums}

Existence of gaps or inadequate laws, rules and regulations in relation to the management of violence phenomenon is another important finding of this study. According to Participant opinions, some of the existing violence returns to management shape and control of violence. In this regard, the interviewee stated that:

"We must see that what is our legal vacuum that the violence hasn't been stopped yet. Dose the absence of warrant timely implementation could be effective? We see that today one fights, but the sentence carry out after four-years.

\subsubsection{Rights of Citizenship}

A society that its mechanisms makes equal legality among people, cause a correct interaction and cooperation among them and correct understanding of each other and finally impact on reducing the incidence of aggression, 
violence and abuse considerably. The incidence of violent behavior is partly due to people's lack of knowledge and education about rights of citizenship and also that how do they follow up their rights?

A participant in this regard said: "One of the reasons of violence in the society, is the insufficient orientation of people with citizenship rights. The first thing that should happen in this society is the definition of a citizen's right and its respect. "When we want to go out of home every morning, In return it's better to take measures that how many times our rights violated".

\subsection{Historical and Anthropological Factors}

\subsubsection{Historical Background}

The historical development of any society affects the quantity and quality of social violence at any time. The discovered ancient objects, which indicate violence and tribal war at thousands years ago, was common. One of the participants stated:

“... This all castles and ancient graves you can see that the most of them have weapons, are not something other than this..."

\subsubsection{Anthropological}

People usually struggling to achieve their goals, whether in social, political, economic or family field. When they face with some barrier and are unable to get rid of them with typical way. Finally the result of this is the feeling of frustration and the production, which this feeling of failure can lead to aggressive behavior.

"Society of animal husbandry because of the incompetence and lack of income in that area, was forced to emigrate city regions. Now $85 \%$ of Ardabil province texture is the rural and tribal population. These people carry out the aggression and violence in their historical memory and genes over thousands of years and flowing them in cities now."

\subsection{Cultural Factors}

\subsubsection{The Quality of Family Relationships}

Because of differences in individual character, violence can forms in the homes and private relationships. These differences are influenced by different cultures between husband and wife, brother and sister or parents and children.

"One of the important components of the prevalence of violence is the quality of family relationships in society. This means that how much is the amount of intimacy and understanding among family members, how much is the insults and contempt to each other".

\subsubsection{Attention to the Next Generation}

The children who expose to physical or verbal violence and insults, In the future they will experience irreversible physical and mental damage. Usually these children when separated from family atmosphere and go to the society may imitate the parent's behavior or have like these behaviors with their child or spouse.

"To the future generation should give more attention. Children, who were trained, should consider more attentively. Those who are over 18 years, I don't say that their changes is not possible, but can be too difficult .A Child who sees that his/her father always insult to mother or vice versa, then he/she learns that in kindergarten must beat other weaker children for taking rights. These all are principal of psychological learning and in the future, he/she enters these principles to society. My intent is the prevention of this crime in a future generation that should give more attention to current children".

\subsubsection{Women Education and Empowerment}

In relation to the level of education and socioeconomic empowerment of women, there were different views among the participants. A group believes that women power can interrupt balancing of management between man and woman and the family foundation. The other group explained that the raising awareness and empowerment of women's as agent for increasing of awareness in them about their rights and is a variable leading to reducing domestic violence.

A participant in regarding of the first theory said: "Now, in our education system the government motto is that more than $60 \%$ of women and less than of $40 \%$ of men in our society are studying. Therefor an educated woman when marries with an uneducated man, this means the difference, namely violence. Namely, that she says I'm bossy and this one, he says, I'm the boss."

And another participant from the opposite group says: "Empowering of women, finally can reduce violence. 
That's mean that one of the causes of violence against women is that she isn't powerful, isn't aware of her rights and had to accede the domestic violence. Raising education of women in the long run, finally can reduce violence".

\subsection{Economic Factors}

\subsubsection{Poverty}

The most triggers of violence and aggressive behavior, are poor social and weak economic. Social violence can't be considered separate from economic circumstances. Violence and hatred is in the light of social developments, unemployment, poverty, lack of jobs and income, force people turn to drug abuse or adopt other ways.

In this regard a participant said: "If you accord the geographic map of Violence and crime in with the geographical map of poverty, you found that more than $85 \%$ of them have overlapped. The main source of Violence in principle, is the economy. Our poor economy only could produce an absolute maximum of between 6-12 percent wealth. In fact, agriculture product poverty rather than create wealth in our province and poverty lead to immigration, Later the immigrant people cause social tensions and social tensions cause crime and judicial records".

And another interviewer told: "If you want to remove violence from the community, you should do something that people could have honorable life with eight-hour working".

\subsubsection{Categories and Economic Gap}

In fact social violence is production of feeling of relative deprivation. When expectations rise in the society and the social groups do not have the necessary means to meet their desired goals, the sense of deprivation prevails and can bring consequences.

"The heart of mental health, is the social justice, we must follow this. Certainly we have a problem with the social justice discussion. Violence is due to increasing of social gaps. In Ardabil province you can see a 5000 million Rials (Note 1) car on the side of Twenty million Rials car in a neighborhood. There is a terrible social gap in Ardabil province. The authorities should do something that this gap comes down. And we're getting closer to social justice. How? With development programs that be closer to social justice."

\subsection{Regional Factors}

\subsubsection{Space and Somatology}

The problems in urban architectural design and lack of forecasting future needs due to problems in urban management on the one hand, and the change in using of residential home of urban, for the purpose of giving health services on the other hand, unintentionally lead to problems in interacts and behaviors of public every day and consequently increase the social violence (e.g. In traffic or waiting in line). In relation to this issue, the interviewer stated:

"The physical space of the urbane is defined only for residential use at its design time. The spatial characteristics such as capacity for people or vehicles pass, all is not defined. We give health care services in a residential home that it causes heavy traffic congestion and there someone act violence and aggression, in fact we have imposed him this violence and aggression. We don't have urban management, over the years, for one time a person with intent of urban development hasn't been in the Department of Housing and Urban Development."

\subsubsection{Bio Ecology}

The features of agricultural land with the broad area and lack of clearly defined borders between each other, is another factor to social aggression and violence, which was also highlighted factor.

In this regarding a participant said:

"When we say that $60 \%$ geographical area of our country is characterized by pasture, farmers who live in it. The stones are picked up as wall and this as a marking border show borders between tribes. Sheep doesn't know sign and border, but the shepherd knows. When an animal pass from the determined border, neighbor Shepherd's react immediately with violation because the privacy has been violated. Thus we can find that anywhere would have agriculture and animal husbandry; there can be too much violence."

\section{Discussion}

In all society, violence known as a threat (Collins, 2014). Disease, stress, anxiety, emotional problems, divorce, lack of jobs, increasing marriage age, inflation, low and insufficient salaries, increasing economic and mental crime and lack of adequate health care, all of these are effective to violence. If a person is placed under stress 
and pressure, social issues inject him/her anxiety and stress on all sides and makes an uncertain and aggressive personality, because he/she can't have harmony and peaceful interaction people in the community. Social, economic and cultural structure of community has been made with applying of policies and programs by the government. If the policy of economic, social, cultural and political couldn't lead to the better living conditions, people show violence and aggression in their behavior (Ruiz, 2009).

One phenomenological study with the title of "exploring experience of job violence in psychiatric nursing wards in Kerman" was performed. The Lack of sufficient staff support and the poor management founded as influencing factors (Ramezani, Fasihi, \& Mangali, 2012). Another qualitative research finding was about the contagious nature of violence and the need to its controlling by using diverse strategies (Moghadam, Pazargadi, \& Khoshknab, 2013).

According to the various studies, the main reasons for hospital violence are the lack of educational programs for the prevention of violence (Soheili, Mohamadpour, \& Jafarizadeh, 2014; Zamanzadeh, Soleyman-Nejad, \& Abdollah-Zadeh, 2007). In a quasi-experimental study, results indicated that education can influence and change attitude to violence (Smaeili, Nabavi, \& Reihani, 2015). The kohestani's study also showed that the education of civil rights was as an effective step to reduction of social violence (Koohestani et al., 2011). According to our findings in this study, the damages associated with social violence, was the low awareness of civil rights.

Moafi's study showed that among factors like poor economic situation has a direct relationship and spouses and women's education, employment, satisfaction from common life and social support have an inverse relationship with domestic violence (Moafi \& Dolatian, 2014). Kamali Zarand indicated the significant relationship between spouse's education, economic situation and domestic violence (Ali Kamali et al., 2015). A study in Santiago showed that inequality between winners and losers in the social, economic and political fields can be creator of violence (Moser, 2012). Our findings have completely consistent with the findings of these studies. Similar to our findings, several studies pointed the need to strengthen social skills such as anger management skills, institutionalization culture of dialogue among the members of the community.

According to the results of Amini's study, control and management of anger, communication skills could reduce the causes of violence (Amini, Heidary, \& Daneshparvar, 2015). Ruiz in his study concluded that violence in multicultural communities may be, because the lack of intercultural dialogue, understanding of different values and norms (Ruiz, 2009). In El Salvador, young people had been known as a threat to social security and thus the government has attempted to implement the repressive policies for protection of citizens against them threat (Peetz, 2008). For authoritative control of the community using of stronger and very violent police, especially among the elite persons has become a general tendency (Hornberger, 2011). Existence legal vacuum and necessity of attention to it, was the emphatic finding of our study.

In designing preventive and intervention-oriented programs, identifying of the causes and roots of violence and identifying those who are at risk in early ages, is very effective (Fritz et al., 2008). If the family as one of the most important institutions in human society can't be effective in controlling aggressive behavior, this can be the beginning of many problems. Whiting et al. studied the intergenerational transmission of violence among the 590 people who were abused as were children in their families, in later, they used violence in social relationships (Whiting \& Simmons, 2009). Our main findings like to these studies (Topham et al., 2005; Huth-Bocks \& Hughes, 2008; Burazeri et al., 2011; McCloskey, 2011) were intimacy, relation in family, the necessity of attention to children and new generation.

The structure of social, economic, cultural and ecological of communities while over the years was institutionalized in society, can be influenced by governmental policies and programs. Economic, social, cultural, and regional policies of the government must be able to regulate and manage the phenomenon of violence to make a proper situation, good and peaceful life accessible to people of society.

\section{Acknowledgements}

This article is a part of research project supported by the Ardabil University of Medical Sciences. The researchers express their gratitude to all the people who contributed to the study.

\section{Conflict of Interest}

The authors declare that there is no conflict of interests regarding the publication of this paper.

\section{References}

Amini, L., Heidary, M., \& Daneshparvar, H. (2014). Mental health and some Socio-Dempgraphic determinations in women with domestic violence experience. The Journal of Urmia Nursing and Midwifery Faculty, 12(8), 
598-605.

Boswell, C., \& Cannon, S. (2012). Introduction to nursing research: Incorporating evidence-based practice. Jones \& Bartlett Publishers.

Burazeri, G., Qirjako, G., Roshi, E., \& Brand, H. (2011). Determinants of witnessed parental physical violence among university students in transitional Albania. Journal of Public Health, 33(1), 22-30. http://dx.doi. org/10.1093/pubmed/fdq034

Cantera, L. M., Cervantes, G., \& Blanch, J. M. (2008). Violence in the workplace: The case of healthcare professionals. Papeles Del Psicólogo, 29(1), 49-58.

Carlson, B. E. (1997). A stress and coping approach to intervention with abused women. Fam Relat, 46, $291-298$. http://dx.doi.org/10.2307/585127

Collier, P. (2003). Breaking the conflict trap: Civil war and development policy. World Bank Publications.

Collins, A. (2014). Violence is not a crime: The impact of 'acceptable'violence on South African society. South African Crime Quarterly, 43, 29-37.

Cozens, P. (2002). Sustainable urban development and crime prevention through environmental design for the British city. Towards an Effective Urban Environmentalism for the 21st Century, 19(2), 129-137.

Fritz, M. V., Wiklund, G., Koposov, R. A., AF Klinteberg, B., \& Ruchkin, V. V. (2008). Psychopathy and violence in juvenile delinquents: What are the associated factors? International Journal of Law and Psychiatry, 31(3), 272-279. http://dx.doi.org/10.1016/j.ijlp.2008.04.010

Hedin, L. W. (2000). Physical and sexual abuse against women and children. Current Opinion in Obstetrics and Gynecology, 12(5), 349-355. http://dx.doi.org/10.1097/00001703-200010000-00003

Hornberger, J. (2011). Policing and Human Rights: The meaning of violence and justice in the everyday policing of Johannesburg. Routledge.

Huth-Bocks, A. C., \& Hughes, H. M. (2008). Parenting stress, parenting behavior, and children's adjustment in families experiencing intimate partner violence. Journal of Family Violence, 23(4), 243-251. http://dx.doi. org/10.1007/s10896-007-9148-1

Kamali et al. (2015). Comparison of domestic violence and its related factors in pregnant women in both urban and rural population in Zarand city. Journal of Clinical Nursing and Midwifery, 4(2), 69-78.

Kaye, D. K., Ekström, A. M., Johansson, A., Bantebya, G., \& Mirembe, F. M. (2007). Escaping the triple trap: Coping strategies of pregnant adolescent survivors of domestic violence in Mulago hospital, Uganda. Scand J Public Health, 35(2), 180-186. http://dx.doi.org/10.1080/14034940600858490

Khanzadeh, A., \& Taher, M. (2014). Analytical study of personality traits juvenile offenders. Criminal Law research, 5(1), 31-53.

Koohestani et al. (2011). Occupational violence in nursing students in Arak, Iran. Iranian Journal of Epidemiology, 7(2), 44-50.

Le Corff, Y., \& Toupin, J. (2009). Comparing persistent juvenile delinquents and normative peers with the Five-Factor Model of Personality. Journal of Research in Personality, 43(6), 1105-1108. http://dx.doi.org/ 10.1016/j.jrp.2009.06.011

McCloskey, L. A. (2011). The impact of intimate partner violence on adolescents.

Mehrtak, M., Vatankhah, S., Delgoshaei, B., \& Gholipour, A. (2014). Succession Planning in the Iranian Health System: A Case Study of the Ministry of Health and Medical Education. Global Journal of Health Science, 6(5), 174-185. http://dx.doi.org/10.5539/gjhs.v6n5p174

Meyer, A., Wagner, B., \& Dutton, M. A. (2010). The relationship between battered women's causal attributions for violence and coping efforts. J Interpers Violence, 25, 900-918. http://dx.doi.org/10.1177/0886260 509336965

Moafi, F., et al. (2014). Domestic violence and its associated factors in Iran: According to World Health Organization model. Pejouhandeh, 19(1), 25-36.

Moghadam, M. F., Pazargadi, M., \& Khoshknab, M. F. (2013). Iranian nurses' experiences of aggression in psychiatric wards: A qualitative study. Issues in Mental Health Nursing, 34(10), 765-771. http://dx.doi.org/ 10.3109/01612840.2012.737893 
Moser, C. (2012). Understanding the tipping point of urban conflict: Participatory methodology for gender-based and political violence. Understanding the tipping point of urban conflict: Violence, cities and poverty reduction in the developing world.

Moser, C. O., \& McIlwaine, C. (2006). Latin American urban violence as a development concern: Towards a framework for violence reduction. World Development, 34(1), 89-112. http://dx.doi.org/10.1016/j. worlddev.2005.07.012

Peetz, P. (2008). Discourses on Violence in Costa Rica, El Salvador, and Nicaragua: Youth, Crime, and the Responses of the State.

Ramezani, T., Fasihi, T., \& Mangali, M. (2012). Nurses' experiences of occupational aggression in the psychiatric wards: Phenomenology approach. Journal of Fundamentals of Mental Health, 13(4), 314-327.

Ruiz, C. C. (2009). Action research against violence: An experience from southern Mexico. IDS bulletin, 40(3), 27-33. http://dx.doi.org/10.1111/j.1759-5436.2009.00035.x

Saberian, M., Atash, N. E., \& Behnam, B. (2005). Prevalence of domestic violence in women referred to the heath care centers in Semnan.

Savenstani, R. S. (2007). Social Pathology: Sociology of Social Deviance. Tehran: SAMT Publications.

Schug, R., GAO, Y., Glenn, A., Yang, Y., \& Raine, A. (2010). The developmental evidence base: Neurobiological research and forensic applications. Forensic psychology, 73-94.

Smaeili, M. H., Nabavi, F. H., \& Reihani, H. (2015). The Effect of workplace violence prevention program on attitudes of nurses towards the management of violence and aggression in patients and their families. Health Promotion Management, 4(1), 79-88.

Soheili, A., Mohamadpour, Y., \& Jafarizadeh, H. (2014). Violence against nurces in emerjency departments of Urmia university hospitals in 2013. The Journal of Urmia Nursing and Midwifery Faculty, 12(9), 873-882.

Speziale, H. S., Streubert, H. J. S., \& Carpenter, D. R. (2011). Qualitative research in nursing: Advancing the humanistic imperative, Wolters Kluwer health.

Taherkhani, S., et al. (2015). Effect of contextual factors on women coping strategies against domestic violence: A qualitative study. Koomesh, 16(4), 581-594.

Talas, M. S., Kocaöz, S., \& Akgüç, S. (2011). A survey of violence against staff working in the emergency department in Ankara, Turkey. Asian Nursing Research, 5(4), 197-203. http://dx.doi.org/10.1016/j.anr. 2011.11.001

Topham, G. L., Larson, J. H., \& Holman, T. B. (2005). Family-of-Origin Predictors of Hostile Conflict in Early Marriage. Contemporary Family Therapy, 27(1), 101-121. http://dx.doi.org/10.1007/s10591-004-1973-2

UNICEF. (1999). Women in transition, regional monitoring report, UNICEF.

Whiting, J. B., Simmons, L. A., Havens, J. R., Smith, D. B., \& Oka, M. (2009). Intergenerational transmission of violence: The influence of self-appraisals, mental disorders and substance abuse. Journal of Family Violence, 24(8), 639-648. http://dx.doi.org/10.1007/s10896-009-9262-3

Zamanzadeh, V., Soleyman-Nejad, N., \& Abdollah-Zadeh, F. (2007). Nature of violence toward nurses working in hospitals of Azerbaijan. Medical Journal of Tabriz University, 29(2), 60-66.

\section{Note}

Note 1. Iran's currency.

\section{Copyrights}

Copyright for this article is retained by the author(s), with first publication rights granted to the journal.

This is an open-access article distributed under the terms and conditions of the Creative Commons Attribution license (http://creativecommons.org/licenses/by/3.0/). 